\title{
Writing Irish Nurses in Britain
}

\author{
Tony Murray
}

This Mass is mostly attended by nurses and navvies, the nurses nice and neat in their white uniforms and blue cloaks and the navvies with their Sunday overcoats on them, trying to conceal the dried mud on their working clothes. ${ }^{\mathrm{I}}$

In April 20I4, during the first state visit by an Irish president to the UK, Michael D. Higgins visited University College Hospital in London to pay tribute to the contribution of Irish nurses to the National Health Service. Whilst the presidential visit was an important recognition of the historical role played by Irish people in Britain, it was criticized in some quarters for not acknowledging the equally significant contribution made by construction workers. ${ }^{2}$ Regardless of the merits or otherwise of this complaint, it remains the case that nurses still have a less conspicuous presence than navvies in popular notions about Irish workers in Britain. Published research into Irish nurses' experiences in Britain, in contrast to that about their male compatriots, is also less common. Studies based on oral history interviews by Bronwen Walter and others have, in recent years, begun to redress this imbalance. ${ }^{3}$ But, published first-hand accounts by Irish nurses in Britain are still rare. ${ }^{4}$ This is all the more surprising given the fact that in

I Donall Mac Amhlaigh, An Irish Navvy: The Diary of an Exile, trans. by Valentine Iremonger (London: Routledge \& Kegan Paul, I964), p. IO2.

2 Ultan Cowley, 'Honouring the Irish Men Who Helped to Build Britain', Irish Times, 7 April 20I4: www.irishtimes.com/blogs/generationemigration/20I4/o4/o7/honouring-the-irish-menwho-helped-to-build-britain/ [accessed 7 August 2015].

3 Bronwen Walter, Outsiders Inside: Whiteness, Place and Irish Women (London: Routledge, 200I); Louise Ryan, "I Had a Sister in England": Family-Led Migration, Social Networks and Irish Nurses', Journal of Ethnic and Migration Studies, 3 (2008), pp. 453-70.

${ }^{4}$ Liam Harte, The Literature of the Irish in Britain: Autobiography and Memoir, I725-20oI (Basingstoke: Palgrave Macmillan, 2009), p. xvi. For other studies of Irish working-class literature in Britain, see Bernard Canavan, 'Story-Tellers and Writers: Irish Identity in Emigrant Labourers' Autobiographies, 1870-1970', in The Irish Worldwide: History, Heritage, Identity: The Creative Migrant, ed. by Patrick O’Sullivan (Leicester: Leicester University Press, I994), pp. 154-69; Patrick 
the middle decades of the twentieth-century nursing was one of the most popular career choices for young female Irish migrants crossing the Irish Sea. ${ }^{5}$

There were a number of reasons why so many Irish women chose Britain to pursue a career in nursing. Places on training courses in Ireland were limited and required the payment of a fee, thus restricting it to largely middle-class entrants. ${ }^{6}$ Nursing also necessitated higher qualifications than it did in Britain. However, while it was less professionalized than in Ireland, nursing still carried a higher status than many other jobs with which Irish women were associated. Margaret Collins, who was interviewed about her experience of coming to London after the Second World War, states, 'You were always told to behave like a lady, they were always comparing what it was to be a nurse to what it was to work in a factory or to work in a shop - you were above that.'7 For young Irish women who were serious about pursuing such a career, migration was, according to Louise Ryan, the only realistic pathway to achieving their goal of becoming a registered nurse'. ${ }^{8}$ When British nurses were in short supply during and after the Second World War, staff were recruited in large numbers from overseas and Irish nurses, in particular, became a sought-after commodity. ${ }^{9}$ Interviews conducted by Bronwen Walter with such nurses record them saying that they had 'always been highly respected' and 'greatly appreciated' for 'their natural empathy'. ${ }^{\text {Io }}$ In her study of class and gender and, in particular, the notion of the 'the caring self', Bev Skeggs identifies nursing as one of the occupations where 'to speak from a caring subject position confers occupational/moral status and authority'. ${ }^{\text {II Walter also argues }}$

Duffy, 'Literary Reflections on Irish Migration in the Nineteenth and Twentieth Centuries', in Writing across Worlds: Literature and Migration, ed. by Russell King, John Connell and Paul White (London: Routledge, 1995), pp. 20-38; Tony Murray, London Irish Fictions: Narrative, Diaspora and Identity (Liverpool: Liverpool University Press, 20I2); Patrick O’Sullivan, 'Patrick MacGill: The Making of a Writer', in Ireland's Histories: Aspects of State, Society and Ideology, ed. by Sean Hutton and Paul Stewart (London: Routledge, I99I), pp. 203-22.

5 Anne Lynch, The Irish in Exile: Stories of Emigration (London: Community History Press, 1988), p. I3. Anita Guidera, 'How Irish Nurses Helped Make the NHS the Envy of the World', Irish Independent, 7 February 2013. www.independent.ie/lifestyle/health/how-irish-nurses-helped-makethe-nhs-the-envy-of-the-world-29051707.html [accessed 3 August 2015].

${ }^{6}$ Enda Delaney, The Irish in Post-war Britain (Oxford: Oxford University Press, 2007), p. 203.

7 Mary Lennon, Marie McAdam and Joanne O'Brien, Across the Water: Irish Women's Lives in Britain (London: Virago, 1988), p. I06.

8 Ryan, "I Had a Sister in England"', p. 459.

9 Clair Wills, The Best Are Leaving: Emigration and Post-war Irish Culture (Cambridge: Cambridge University Press, 20I5), p. 8I.

10 Bronwen Walter, Irish Women in London: The Ealing Dimension (London: London Borough of Ealing Women's Unit, 1989), p. 87.

"I Beverley Skeggs, Formations of Class and Gender: Becoming Respectable (London: Sage, 1997), p. 69. 
that nursing was 'related to dominant images of women in Ireland, to notions of caring and self-sacrifice directly reflecting Catholic values' ${ }^{12}$ In the predominantly Catholic communities from which most Irish nurses came, such values were embodied by the Virgin Mary. In the context of the British health system, one can see how such a figure would have mapped relatively seamlessly onto the iconic image of Florence Nightingale. ${ }^{13}$ This 'positive stereotype' of Irish nurses stood in sharp contrast to the rather more negative one of the Irish navvy in Britain. ${ }^{14}$ This may have been one of the reasons why this particular representation of Irish workers in Britain was favoured during the presidential visit.

Apart from its favourable status in public perceptions, there were more practical reasons why nursing was an attractive option for young Irish women. One was that it was an occupation which, unlike navvying, came with secure accommodation. As Henrietta Ewart points out, this was recognized by British hospitals as an asset when it came to recruiting badly needed staff in Ireland and glossy brochures were produced for this precise purpose. ${ }^{15}$ Nancy Lyons, who joined Paddington Hospital as a trainee nurse in 1943 , records how thrilled she was to get her own room in a nursing home. Work was hard and the hours long, but, she points out, 'there was such a lot of staff looking after you. ${ }^{\text {'6 }}$ Such an environment also had the advantage of providing the often lonely young recruit with a readymade social circle of fellow workers and compatriots. ${ }^{17}$ Kathleen Henry, for instance, who joined the National Hospital in Queen Square, London, in the early I950s, enjoyed going out to concerts and the theatre with her peers. ${ }^{18}$ By far the most popular entertainment, however, was dancing, not least because it provided the best means by which young nurses met potential partners. The generally positive picture of nursing presented in oral history interviews, however, is not universal. Maira Curran, for instance, who took up a position at the Royal Northern Hospital in Holloway in 1948, recalls being so unhappy that she attempted to commit suicide. ${ }^{\text {I9 }}$

\footnotetext{
12 Walter, Outsiders Inside, p. I79.

${ }^{13}$ For the role played by an Irish nurse in Nightingale's mission, see Therese Meehan, 'The Irish Connection', World of Irish Nursing, i9 (2010), pp. 28-9.

${ }_{14}$ Walter, Outsiders Inside, p. I8o.

is Henrietta Ewart, 'Perfecting the Honour of the Daughters of Eire: Welfare Policy for Irish Female Migrants to England, I940-70', Irish Studies Review, I (2013), pp. 7I-84 (p. 79).

${ }^{16}$ Lennon et al., Across the Water, p. I73.

${ }_{17}$ Louise Ryan, 'Migrant Women, Social Networks and Motherhood: The Experiences of Irish Nurses in Britain', Sociology, 2 (2007), pp. 295-3I2 (pp. 300-I).

I8 Pam Schweitzer, ed., Across the Irish Sea (London: Age Exchange Trust, 1989), p. 9I.

19 Schweitzer, ed., Across the Irish Sea, p. 60.
} 
Between them, the three texts I examine in this chapter recount experiences of Irish nurses in Britain between the late I930s and the early I950s. Whilst they celebrate many of the positive features of nursing life referred to already, they are also highly critical of certain aspects of the institutions and regimes under which they trained and served. As such, they provide somewhat fuller and more discursive accounts of the occupation than oral history testimonies are usually able to do. Given the juxtaposition of nurses and navvies in debates about the presidential visit of 20I4, I also compare these accounts to those of Irish construction workers during the period in order to explore similarities and differences, particularly across gender. The three accounts I have chosen to analyse consist of a diary, a memoir and a semi-autobiographical novel and offer the opportunity to compare a key set of experiences within a focussed historical time frame across different prose genres. Popular memoir is sometimes criticized as shallow and manufactured, but a recent study argues that it has enhanced perceptions of the relationship between personal testimony and historical understanding by offering 'the potential to change the imagined relations their readers have with the lives of others'.$^{20}$ The three texts I examine here make an important contribution to this process.

Having attracted little or no attention while lodged in the vaults of the Imperial War Museum's archives, Mary Morris's diary of her nursing experiences during the Second World War was published in 20I4. By ensuring its publication, its editor, Carol Acton, opened a window onto a hitherto obscured aspect of working women's lives in wartime Britain. Very few diaries, she informs us, survived the war and Morris's is 'unusually complete and sustained'. ${ }^{21}$ Furthermore, she points out in an earlier essay that the absence of any reference to Morris's nationality in the archive catalogue resulted in the occlusion of an important contribution by Irish workers to the British war effort. ${ }^{22}$ Morris left her family home near Caltra in County Galway at eighteen years of age to begin her nurses' training at Guy's Hospital on the eve of the Second World War. Although she was well-educated, there was little prospect of employment in the rural west of

${ }^{20}$ Julie Rak, Boom!: Manufacturing Memoir for the Popular Market (Waterloo: Wilfred Laurier University Press, 2013), p. 4.

${ }^{21}$ Mary Morris, A Very Private Diary: A Nurse in Wartime (London: Weidenfeld \& Nicolson, 20r4), p. xv. Subsequent references are indicated in parentheses in the text. For earlier examples of memoirs about Irish nursing in Britain, see Annie M. P. Smithson, Myself - and Others: An Autobiography (London: Talbot Press, 1945); Emily E. P. MacManus, Matron of Guy's (London: Andrew Melrose, 1956).

${ }^{22}$ Carol Acton, "'Stepping into History": Reading the Second World War through Irish Women's Diaries', Irish Studies Review, I (2010), pp. 39-56 (p. 40). 
Ireland in 1939 and so, like so many of her peers, she took the mail-boat to England. Whilst relatives and friends back home took some persuading that she was not living in 'a hornets' nest of evil, danger and Godlessness' (I8), Morris seems, on the whole, to have had support from those who knew her. In her research on Irish women workers in Britain during the Second World War, Mary Muldowney discovered that war conditions in Britain created opportunities for Irish women and 'enabled some of them to fulfill ambitions or to develop personally in ways that would not have been possible before the war started'. ${ }^{23}$ Mary Morris was clearly a beneficiary of this.

One year after Morris's diary appeared, Sixty Years a Nurse (2015) by Mary Hazard was published by HarperElement, an imprint which specializes in popular memoir. While there has been a surfeit of such books about British nurses, there are (despite their numerical significance) remarkably few references to the Irish as a distinct cohort of the workforce. ${ }^{24}$ Hazard left Clonmel in south-west Ireland in September 1952 to begin her three years of nurses' training at Putney Hospital in London. Her sense of adventure at travelling to the metropolis is palpable. 'It was so exciting,' she exclaims. 'My first plane journey, ever ... I felt very grown-up, all on my own, with my little bag neatly stowed overhead and my new shiny black Clarks shoes on my feet ... I was finally on my way to fulfil a life-long ambition. ${ }^{25}$ The fact that Hazard was still only seventeen years of age provides a possibly unintended ironic counterpoint to what she describes as her 'life-long ambition', but, as she goes on to explain, she had 'wanted to be a nurse for as long as [she] could remember' (5). As is apparent from her mode of transport to England, Hazard came from quite a well-off background ( 5 ). She encountered considerably more resistance from her family than Morris, but she makes very clear how determined she was to escape their 'rigid, cruel control' and to succeed at her chosen profession (3).

The third text, Florrie's Girls (1989) by Maeve Kelly, remains the only novel wholly dedicated to portraying an Irish nurse's experience of working in Britain. Kelly, who was born in Ennis, Co. Clare, trained as a nurse at St Andrew's Hospital in east London in the 1950s, and the fictionalized diary of which the novel consists is clearly based on these experiences. ${ }^{26}$

${ }_{23}$ Mary Muldowney, 'New Opportunities for Irish Women? Employment in Britain during the Second World War', University of Sussex Journal of Contemporary History, Io (2006), p. 2 [individual papers published separately online - no page range].

24 See, for instance, Maggie Holt, A Nurse at War (London: Random House, 2013), p. 68.

${ }_{25}$ Mary Hazard, Sixty Years a Nurse (London: HarperElement, 2015), p. I. Subsequent references are indicated in parentheses in the text.

${ }_{26}$ Patricia Feehily, 'Proving Comedy Is Undeveloped Tragedy', Limerick Leader, 28 October I989, p. 6. 
As such, it is comparable to the other texts but also provides a creative counterpoint to their more formally historical accounts. Caitlin Cosgrave (Cos), the heroine of the novel, has entirely different emotions to her peers about leaving Ireland. On the day she takes the train to Dublin doubts about her decision to leave abound. So overwhelming is her desire to turn back that she even admits, in retrospect, that she 'should have pulled the communication cord and leaped out of the carriage window'. ${ }^{27}$ But, she philosophically adds, 'we get on the train and we keep moving because the train is on its tracks and it's easier to go with it than to get off' (I).

The initial introduction to their training in Britain was often a disillusioning one for young nurses. The sheer amount of cleaning they were expected to do was not something for which student nurses were necessarily prepared. ${ }^{28}$ Cos lists the numerous domestic chores she is expected to perform before she even begins to think about attending to the sick: 'scrubbing the cupboards, the bedpans, the soiled sheets, the walls, the doors, the sinks, the floors, the windows, the ceilings.' 'I stank of carbolic,' she protests. ${ }^{29} \mathrm{Her}$ greatest disapproval, however, is reserved for the repulsive duties of the sluice room, where trainee nurses are required to hand-wash dirty bed linen. This tests the resolve of even the most committed trainees, in much the same way as digging ditches does for novice navvies. On his first day at work, Pat Moore, the hero of Walter Macken's novel I Am Alone (1949), complains of a succession of blisters breaking out on his hands. Likewise, Donall Mac Amhlaigh records how he was 'hardly able to straighten [his] back next morning when [he] was getting up..$^{30}$ After a morning in the sluice room, Cos writes in her diary, 'My arms ached at the end of it. They still ache and my shoulder muscles are strained' (5). Meanwhile, Mary Hazard's hands 'became raw from washing and scrubbing all the time, immersed in carbolic and disinfectant'. ${ }^{3 \mathrm{I}}$ In what is

${ }_{27}$ Maeve Kelly, Florrie’s Girls (London: Michael Joseph, I989), p. I. Subsequent references are indicated in parentheses in the text. For earlier examples of fictional portrayals of Irish nurses in Britain, see Mrs Samuel Carter Hall, 'Hospitality', in her own Sketches of Irish Character (London: M.A Nattali, I844), pp. I35-54; John McGahern, The Barracks (London: Faber \& Faber, 1963).

${ }_{28}$ For evidence of this in oral history accounts, see for instance, Kathleen Ruth, Audio Collection, Archive of the Irish in Britain, London Metropolitan University.

29 Kelly, Florrie's Girls, p. 3I. For an even more damning condemnation of the hospital regime in London, see Maeve Kelly, 'Morning at my Window', in Orange Horses (London: Michael Joseph, I990), pp. 20-8.

3o Walter Macken, I Am Alone (London: Pan Books, I977), p. 35; Mac Amhlaigh, An Irish Navvy, p. 3I. For other examples of fictional portrayals of Irish navvies in Britain, see Patrick MacGill, Children of the Dead End (London: Herbert Jenkins, I9I4); Richard Power, Apple on a Tree Top (Dublin: Poolbeg Press, 1980); Padraic Breathnach, As Na Culacha (Galway: Clo Iar-Chonnachta, I998); Philip Casey, The Water Star (London: Picador, 1999); Peter Woods, Hard Shoulder (Dublin: New Island, 2003).

${ }^{31}$ Hazard, Sixty Years a Nurse, p. 36. 
otherwise a much more optimistic take on the experience of an Irish nurse in Britain at this time, Bridget Dunne is just as emphatic in her memoir about how much she hated this aspect of her training. ${ }^{32}$ Whether sluice or ditch, such tasks appear to constitute a 'rite of initiation' which nurse or navvy must endure in pursuit of their chosen occupation.

All three nurses are unanimous in their criticism of poor pay and conditions. On $£$ IO a month, Hazard was required to save up for luxuries such as fashion items, and learn to 'make-do-and-mend' (26). She recalls how she and her fellow trainees were often hungry because, although meals were ample, they were infrequent. This meant that they regularly worked long shifts without sufficient sustenance. Morris describes the diet provided as 'totally inadequate'. 'I feel so faint from hunger', she declares, 'that it is almost impossible to carry out my innumerable duties' (34). This is exacerbated by being required to serve food to patients while hungry herself. She explains that even on her day off, her meagre wages don't allow her 'to go out for a meal' (I8). The lack of adequate sustenance is apparent also in Florrie's Girls. Such are Cos's pangs of hunger, she is driven to smoking as a means of coping with them. The irony of this does not escape her. 'I don't suppose it's very healthy', she reflects, 'But then, who said hospitals were healthy? As Aunt Maggie always said, you'd want to be in the full of your health before you'd go into one of those places' (27). Despite such jocular reflections, it is surprising, however, the degree to which the nurses' own health is compromised by the conditions in which they work, especially given the nature of their occupation. ${ }^{33}$

The harshness of the managerial system under which nurses trained also comes in for some robust criticism. This is starkly evident in one of Morris's first entries (3I May 1940) when she records how Staff Nurse Jones 'reduced [her] to tears twice before the 9 a.m. break' (3). By September, she is openly critical of the inflexible hierarchy that operates in the hospital. After informing a consultant about an urgent telephone call for him, Morris is reprimanded by the ward sister. 'I slunk off', she writes, 'wondering what I had done wrong this time, but was soon to learn that junior nurses must never presume to talk to a consultant - messages must always be conveyed via Sister or Staff Nurse' (33). For Hazard, escaping the strictures of her upbringing and the emotions associated with it prove difficult

32 Bridget Dunne, Journey into the Unknown (London: Temple Publishing, 1995), p. I5. N.B. Limitations on space preclude me examining this text in depth.

33 For an alternative view of nurses' nutrition, see Mollie Kissane, 'An Irish Nurse in East Sussex, Part I' www.bbc.co.uk/history/ww2peopleswar/stories/96/a56IO296.shtml [accessed 3 August 2015]. 
within the equally autocratic system she is subject to in Putney. 'Matron and Sister Margaret' are, she reflects, 'my mother and God all merged into one all-seeing, omnipresent eye'. 'I was always its beady focus', she protests, 'I was always in the wrong and needing to do penance as a sinner' (72). She also records how 'racism abounded, unchecked' (33). In a revealing insight into the racial pecking order that applied in regards to employment, Hazard quotes one particular matron saying to her trainees, 'I'll take the Irish, because I need you, but I don't have to take the coloureds' (33). Irish nurses, however, did not always find themselves in such a favourable position. As the record of an Irish parliamentary debate reveals, the precise obverse of this view was expressed by the matron of a large London hospital in $1967 .{ }^{34}$ As Hazard's memoir develops, she is increasingly critical of the hospital system. 'There was a constant tension', she writes, 'between meeting the needs of the regime, so that rules were followed and things were done perfectly, and meeting the needs of the patients, who needed time, nursing and care' (78). When she begins to question some of the procedures, however, she is quickly and firmly put in her place. 'We lesser mortals', she writes, 'had to sacrifice ourselves on the altar of duty' (IOS). After an incident in which Hazard was forced by the ward sister to substitute for the hospital cook, she learns the importance of not being coerced by her superiors into duties beyond her job description. ${ }^{35}$ As the memoir progresses, she gradually begins to appreciate the importance of collective bargaining and is persuaded by a colleague to join the Royal College of Nursing. Eventually, she transcends the powerlessness of her position by finding herself a role as a union representative. ${ }^{36}$

The hospital regime also comes in for direct criticism in Florrie's Girls. 'The hierarchy is unbelievably rigid', writes Cos, 'Worse than school' (7). 'After all', she muses, 'perhaps it is we, the little worms, who hold the hospital edifice up. Perhaps it would all come tumbling down if we were not here' (II4). Predictably, the ogre of the ward sister (represented here by the character of Maguire) makes an early appearance. Cos tells us she is 'the most terrible person I have ever met' and even confesses to having nightmares about her. Like Hazard, Cos appears to be singled out for special attention. 'It seems that I am her crucifixion, her crown of thorns,

\footnotetext{
34 Dáil Éireann Debates, Volume 226, Number 6 at: http://oireachtasdebates.oireachtas.ie/debates\%20 authoring/debateswebpack.nsf/takes/dailı9670208000I4?opendocument [accessed 28 August 20I5].

35 Hazard, Sixty Years a Nurse, pp. 169-70.

${ }^{36}$ An anonymous personal account in the Irish Democrat in January I95I reveals the prominence of Irish nurses in a campaign for better working conditions in a British hospital. 'They Treat us Like Dirt', Irish Democrat (January I95I), p. 4.
} 
the sword in her side, and she lets me know it as often as she can' (3). Given her surname, it is likely that Maguire (like Cos) is an Irish Catholic, something which may account for the way this description is dressed in biblical imagery. A parallel with the Irish nurses' compatriots on the building sites is apparent here. Complaints made about ward sisters echo those made by navvies about gangers (site supervisors), many of whom were also Irish. ${ }^{37}$ The only time when the authority of the ward sisters was overruled was when the matron appeared, or when it came to ward rounds. In the following passage, Hazard fashions this moment into a graphically memorable image:

We trailed behind the doctors and consultants in their crisp white coats and pin-striped suits, stethoscopes slung round their necks, as they pronounced on the patients and snapped their orders with military precision. We were like well-behaved little goslings following behind giant ganders. (40-I)

The gendered nature of the hospital regime is clearly apparent here. In Florrie's Girls, Cos's overt criticism of male authority figures and the inherent sexism and misogyny encountered by nurses belies Maeve Kelly's distinctly feminist agenda. When a young woman is operated on after contracting an infection from a back-street abortionist, Cos confronts the surgeon about prejudicial comments he makes about her lifestyle. But she is dismissed by him as 'the little fire-eater intent on demolishing the hospital system' (212). Her most vitriolic criticism is reserved for a certain Mr McCrann, a consultant in a women's clinic whose ward-round leaves Cos seething with anger at the manner in which he openly discusses the patients' sex lives in front of the nurses. 'It was all wrong, wrong, wrong,' she protests ( 152 ).

Despite the obvious deficiencies of their chosen career, all three authors were, as the texts demonstrate, nevertheless able to appreciate the more humorous side to their predicament. In keeping with the generally upbeat tone of her memoir, Hazard compares her experiences as a trainee to the comic feature film Carry On Nurse (1959) (3I). She admits to having been a somewhat clumsy student nurse, whose analogue in the film is Stella Dawson (played by Joan Sims), whilst Maguire is mirrored in the character played by Joan Hickson. The near farcical nature of hospital life is never far from Cos's thoughts either. She describes how, on one occasion, a male patient finds himself in hospital as a result of a violent dispute over

37 Ultan Cowley, The Men Who Built Britain: A History of the Irish Navvy (Dublin: Wolfhound Press, 200I), pp. 198-20I. 
a woman. The ward sister, who removes his stitches with a certain gusto, believes that the patient deserves no sympathy. 'What can men do?', she asks. 'Fight. Build things up so that they can tear them down. That's what men do' (73). For a moment, this casual comment appears to promise further insights into the way some nurses viewed their compatriots on the building sites ${ }^{38}$ However, the scene quickly descends into slapstick humour after one of the consultants intervenes unbidden. When the ward sister attacks him with a scissors, she loses her balance and falls (in arch Carry On style) on top of the patient in the bed. Like Morris and Hazard, therefore, Kelly demonstrates, through her alter-ego, Cos, that she can appreciate the comic as well as the serious side to gender relations within the hospital system.

As noted previously, one of the perceived advantages for young Irish women of training to be nurses in Britain was the fact that accommodation usually came with the job, guaranteeing a safer and more secure environment than would have been the case had they been obliged to find 'digs' in the private rental sector. However, this came with its drawbacks. The supervision of nurses in their lodgings fell to the home sister, who, amongst other things, was responsible for ensuring that all nurses were in their beds at a suitable hour, typically by I0.30 at night. ${ }^{39}$ The rule about 'lights out' was particularly problematical when the nurses had an evening off and were obliged to leave early to ensure they were not locked out of the home. Coming back late from an evening's dancing, Hazard and her fellow student nurses are forced to find an alternative means of gaining entry to the building. It was common practice in nursing homes for at least one nurse to leave her bedroom window discreetly open before going out for the evening. In Hazard's case, the task falls to a nurse called Kathleen so that her fellow trainees can all 'clamber in late'. Carry On Nurse springs to mind again as Hazard and her colleagues, all 'a bit tipsy and high on the adventure' land 'in a heap in Kathleen's room' (138). The motif of 'the open window' also appears in Morris's text. After a night out for dinner in Tunbridge Wells with her French boyfriend, she describes how he helped to push her through one such window after dark. She writes, 'It was a real cloak-and-dagger effort to get to my room without being spotted by the eagle-eyed Home Sister' (8). On this particular occasion, however, Morris

${ }^{8}$ The ward sister's choice of words closely resembles the title of a popular ballad about Irish navvies in Britain. See Dominic Behan, 'Building Up and Tearing England Down' (1965).

39 Not all nurses necessarily criticized such restrictions, emphasizing instead the benefits for young and sometimes naïve young women of clear boundaries. See Dunne, Journey Into the Unknown, p. I4. 
is evidently unsuccessful in her mission and the following day she is summoned to the Matron's office:

I waited to be admitted to the presence. She is such a terrifying figure as she sits behind her large desk in full regalia - severe navy dress with stiff starched collar, starched cap with frilly edges and a large bow tied under the medley of chins, all of them voicing disapproval. (9)

Similarities with Hazard's description of this infamous symbol of hospital authority are evident here but so too is Morris's skill at exacting a ruthless comic effect.

If uniforms symbolized the constraints of the hospital regime, the following passage in Hazard's memoir reveals how they also indicated how such young women had devoted themselves to a potentially valiant vocation:

We had waist-length navy-blue woolen capes with a fabulous crimson lining, which we wore over our uniforms. It was a real Florence Nightingale touch and I felt wonderful in mine. They had red cross-over tapes to keep them in place - oh, I did feel like a proper nurse as I flounced along, my cape swishing in the wind. $(27-8)$

The figure of Florence Nightingale is mediated here (as it is in the title of Kelly's novel) into a symbol of mid-twentieth-century Irish migrant experience in much the same way as the mythical figure of Cuchulain is invoked in contemporaneous 'navvy narratives' where feats of physical prowess by Irish construction workers are described. ${ }^{\circ}$ Such heroic notions are apparent in Cos's earliest entry in her diary. 'My heart was down in my boots to be leaving', she declares, 'but I consoled myself with the thought that at long last I was doing something noble' (I). Six months into her training at St Monica's, however, she is having second thoughts. 'So far I don't feel the least bit noble', she writes, 'I feel frazzled' (2). In time, she fantasizes about putting an advertisement in the local paper, reading, 'Ennobling experience for sale. Bargain offer. Low reserve. Going cheap. Very cheap' (72). Despite the mischievous tone of this entry, Cos's frustration and disappointment are unmistakable. Like her peers, it is only when the relatively rare opportunity arises to offer one-to-one care for individual patients that she is able to affirm her raison d'etre and her determination to continue nursing. 'It is truly amazing', she says, 'how much pleasure is to be had in caring for people and making them feel better' (38). In contrast to the

$4^{\circ}$ Tony Murray, 'Navvy Narratives: Interactions between Fictional and Autobiographical Accounts of Irish Construction Workers in Britain', in Ireland: Space, Text, Time, ed. by Liam Harte, Yvonne Whelan and Patrick Crotty (Dublin: Liffey Press, 2005), pp. 209-I7. 
accounts by their male counterparts referred to earlier, the heroic associations of a nursing career soon give way to a more personal and meaningful sense of job satisfaction.

Cultural differences between the Irish and the English come under scrutiny, to a lesser or greater extent, in all three texts. Morris does this by highlighting the role of social class and accent in her diary. She discovers that 'the type of colonel's lady who looks down her nose at my soft Irish brogue will be charm itself if I teasingly adopt an Oxford drawl' (7). Morris's use of the word 'teasingly' suggests that, despite such an intimidating working environment, she has the self-confidence and linguistic facility to exploit circumstances for her own advantage when she needs to. Cos's awareness of class is refracted through even stronger references to national or nationalist identity. When she observes how 'The English place a lot of importance on uniforms', she supposes this 'is because they are so class-aware'. 'The Irish are not neat and tidy,' she declares. 'The day we get neat and tidy with lawns and garden gnomes is the day we will have forgotten how to live ... Things should fall into place and should be allowed to happen without too much pushing. It's the pushy people who create disorder. The takeovers and colonizers and conquerors' (78-9). When her Irish colleague Hanly begins courting an English doctor, Cos is not convinced that she will be able to adapt to English customs, prompting a strong patriotic declaration. 'It would wear me out,' she announces. 'And it would wear me out having to forget all that I am, all that I am rooted in and the thousands of years that went into making me what I am' (I62). Awareness of a cultural clash between Englishness and Irishness, therefore, is more pronounced in Cos's case than in that of her peers.

As Cos nears the conclusion of her training, she resorts to increasingly lengthy and contemplative entries in her diary that explore deeper feelings about her chosen profession. Writing, in effect, becomes a way by which she confronts her ambivalence about this but also increasingly asks complex questions about her sense of identity. In the following passage she sets up a rhetorical opposition between her rural Irish background and the urban English culture to which she is becoming accustomed, while simultaneously exposing the extent to which the hospital's institutional hierarchies are acutely gendered:

I often think of the winds of home, the way they whine and wail outside our house and make the trees crooked and strip them bare. We are out of touch with winds and stormy weather here because we don't have to work in them. We are wound up like clockwork dolls and do the bidding of people who have no sense and not much intelligence. We clean and 
tend and administer to people who come and go with their ailments big and small. We prepare them for their masters the surgeons. We prepare the sacrificial table and clean the knives and hand everything over to men who cover themselves in green cloths and hide their expressions behind masks as they pretend to be gods and we pretend to be their handmaidens. (200)

Cos begins to realize, therefore, how she and her colleagues have become mere cogs in the hospital machine. As a consequence, they are reduced to performing empty institutional rituals rather than caring for their patients in a meaningful way. On a personal level the sense of loss for Cos here is palpable. By powerfully evoking elemental imagery of the Irish countryside, she portrays a younger more innocent self being sacrificed to a work ethic which demands total commitment, if not capitulation. Even for Morris, who is generally less emotionally forthcoming, her occasional trips back to Ireland excite unambiguous declarations of belonging. In June 1940, she records her delight at 'hearing familiar Irish voices' on the mail boat from Holyhead to Dublin, and 'the happy laughter of people going home to their families, glad to get away from the black-out of London'. The 'smell of the boat to Ireland always excites me,' she writes, and after a hearty Irish breakfast in Dublin, she declares, 'It was bliss. I was home' (II-I3).

Writing for Morris, however, does not entail quite the same degree of cathartic release as it does for her two peers. This is, perhaps, because hers is a more clandestine and proscribed text. If the least mediated of the three narratives, it nevertheless belies the skills of an experienced prose stylist, as evidenced by her evocative descriptions of the London Blitz (38). By the end of her diary she has a developed literary sense of a reader (albeit an imagined one) and is clearly concerned to maintain high standards in regards to the quality of her writing. This is evident, for instance, in her withering critique of a suitor's attempts at poetry. ${ }^{4 \mathrm{I}} \mathrm{It}$ is apparent that writing has also played a formative role in Cos's personal development over the period of her training. She prophetically observes near the beginning of the diary that 'talking about things sometimes makes them worse' and 'writing about them makes them worse too', but 'at least it makes them clearer' (2I). The sense of immediacy and contemporaneity in Morris and Cos's diaries is not so evident in Hazard's memoir, which by definition is more retrospective. But Hazard's backward glance has the virtue of greater objectivity. This enables Hazard to situate her nursing experiences in the

${ }^{41}$ Morris, A Very Private Diary, 6I. 
wider context of her national and family inheritance, in mid-twentiethcentury labour relations and in women's migration more generally.

Memoirs and diaries (fictional or otherwise) provide scope for their subjects to write at length about the day-to-day routine of their working lives in a way that is not so true of oral testimony. That routine, in the case of Irish nurses, was often tedious and repetitive. The pay was poor and the conditions were tough. That is abundantly clear from all three of the accounts explored here. But as Hazard declares, 'the camaraderie was fantastic' (I27). Having chosen her path and followed it, she concludes. 'I was happy in my choices' (264). Even in the case of Cos, who decides by the completion of her training that she is temperamentally ill-suited to nursing, her honesty and bravery in the face of ultimately insurmountable obstacles is admirable. Narrative, in one form or another, therefore, enables the three authors to come to terms with the challenges they face as student nurses. In the case of $A$ Very Private Nurse, this takes place contemporaneously, whilst in Sixty Year a Nurse it is retrospective. In Florrie's Girls, it is a mixture of the two processes, contemporaneous if read through the character of Cos, but retrospective if read through from the semi-autobiographical perspective of its author. In all three texts, narrative provides a sense of time passing, conditions changing and characters evolving. This enables us as readers to share, empathize and begin to understand the lives and environments of three representative Irish female workers in mid-twentieth-century Britain. What is ultimately most striking about these texts is the way all three authors employ prose narrative to not simply record events about their lives, but also to manage and mediate their feelings about those events and adjust to migration and their working environment. In this regard, the books clearly have a cathartic and self-affirming function for their authors as well as providing a historically informative resource for their readers.

\section{Acknowledgments}

I would like to thank Ethel Corduff for her invaluable assistance with information about Irish nurses in Britain. 